\title{
SURAT 1 PETRUS DAN MISI: SEBUAH PERSPEKTIF
}

\author{
Oleh: Irfan F. Simanjuntak
}

\begin{abstract}
Abstraksi: Artikel ini bertujuan untuk menunjukkan bahwa surat 1 Petrus adalah sebuah tulisan yang bermotif misi dan ditulis dengan kesadaran misi yang tinggi. Sekalipun surat ini tidak memuat dua kata paling signifikan yang berkaitan dengan misi, yakni ekklesia dan euangelizethai--yang menyebabkan banyak orang meng-klaim jika kitab ini tidak memiliki motif misi sama sekali, 1 Petrus merupakan gudang data tentang misi yang memberikan perspektif yang luas tentang misi. Dalam surat ini misi dikaitkan dengan identitas orang Kristen. Artinya menjadi Kristen berarti memanggul misi di pundaknya. Di samping itu misi juga dikaitkan dengan penderitaan, bukan dalam pengertian misi menghasilkan penderitaan melainkan melalui penderitaan misi tetap dapat dilakukan. Melalui surat ini juga dapat dilihat bahwa misi dapat dilakukan dengan cara, yaitu melalui pelayanan, perbuatan dan perkataan. Melalui penelitian yang intensif terhadap surat 1 Petrus, artikel ini akhirnya menyarankan sebuah redefinisi yang berkaitan dengan misi. Redefinisi tersebut diharapkan dapat meningkatkan kesadaran dan vitalitas orang Kristen dalam melaksanakan misi.
\end{abstract}

Kata-kata Kunci: Petrus, misi, orang percaya

\section{PENDAHULUAN}

1 Petrus adalah sebuah surat yang oleh banyak sarjana dikategorikan sebagai bersifat misi. Tentu saja untuk membuktikan statemen ini diperlukan sejumlah upaya yang serius. Robinson berkata, 1 Petrus absen dalam hal dua kata paling signifikan tentang 
REAL DIDACHE: JURNAL STT REAL BATAM Vol. 2 No. 1 (Maret 2017)

misi di dalam Perjanjian Baru, yaitu ekklesia dan euangelizethai. ${ }^{1} \mathrm{Hal}$ ini dapat menyebabkan seseorang, secara kontras, menyimpulkan bahwa 1 Petrus tidak menyinggung apapun tentang misi. Tapi apakah pendapat tersebut benar adanya? Benarkah 1 Petrus tidak berbicara tentang misi sama sekali? Pertanyaan-pertanyaan tersebut perlu untuk dijawab karena jawabannya berkaitan erat dengan natur kehidupan orang Kristen; "pendatang dan perantau" di dunia ini (band. 2:11). Sebagai pendatang dan perantau, apa yang harus dilakukan di dunia ini? Jawabannya akan menunjukkan bagaimana orang Kristen menghadapi pergumulannya di dunia ini-sama seperti para penerima Surat 1 Petrus.

Oleh karena 1 Petrus adalah sebuah surat kepada orang Kristen perantau, tentu saja, adalah mungkin untuk memahami surat ini sebagai bersifat misi. 1 Petrus, menurut Steuernagel, adalah "sebuah surat yang memanggil dan mengundang orang-orang Kristen untuk menghadapi penderitaan, namun di saat yang sama untuk pergi dan membagikan kepada sesamanya anugerah kehidpan yang luar biasa itu, terlepas dari siapapun mereka."2 Pendapat ini tentu saja dapat ditemukan dukungannya di surat ini dan observasi berikut akan menunjukkannya.

${ }^{1}$ P. J. Robinson, "Some Missiological Perspectives from 1 Peter 2:4-10" dalam Missionalia 17 (1989): 1.

${ }^{2}$ Valdir R. Steuernagel, "An Exiled Community as a Missionary Community. A Study based on 1 Peter 2:9, 10" dalam Evangelical Review of Theology 10 (1986): 8. 
Dengan demikian, studi ini adalah penting. Sebagaimana kita ketahui, Kekristenan dan misi sangat terkait erat, demikian Glasser, "mandat di dalam Kitab Suci sangatlah jelas: Orang Kristen dipanggil untuk memproklamirkan Kabar Baik kerajaan kepada semua orang." Dalam nuansa yang sama Bosch berkata," iman Kristen secara intrinsik adalah misionary." 4 Dan surat 1 Petrus adalah "gudang data" untuk teologi misi.

\section{PERSPEKTIF MISI DALAM 1 PETRUS}

1 Petrus merupakan surat pastoral yang dikirim oleh Simon Petrus sang Rasul. Tentu saja banyak sarjana yang akan menolak pendapat ini. Pendekatan kritis terhadap kepenulisan Petrus telah dimulai di awal abad kesembilan belas, dimana pendapat yang umum diterima menyatakan bahwa 1 Petrus dikategorikan sebagai tulisan pseudepigrapis. Artinya ia merupakan "sebuah teks yang ditulis oleh pengarang yang lebih kemudian yang memakai nama Petrus sebagai pengarang surat tersebut." ${ }^{5}$ Seperti yang diungkapkan oleh Schnelle, "ada banyak pertimbangan yang berbicara secara kuat menentang

${ }^{3}$ Arthur F. Glasser and Donald A. McGavran, Contemporary Theologies of Mission (Grand Rapids, MI.: Baker Book House, 1983), 7.

${ }^{4}$ D.J. Bosch, Transforming Mission: Paradigm Shifts in Theology of Mission (New York: Orbis Books, 1991), 8.

${ }^{5}$ Donald P. Senior, Sacra Pagina: 1 Peter, ed., Daniel J. Harrington (Collegeville, Minnesota: The Liturgical Press, 2003), 5. 
kepenulisan Petrus." ${ }^{6}$ Tapi, karena tujuan dari karya tulis ini adalah bukan untuk membicarakan kepenulisan 1 Petrus secara luas, adalah lebih baik untuk mempersingkat perihal kepengarangannya. Bagaimanapun juga, surat ini dimulai dengan mengatakan pengarangnya adalah Petrus (1:1) dimana ia juga menyatakan bahwa dirinya adalah saksi dari penderitaan Kristus (5:1), dan argumenargumen yang mendukung kepenulisan Petrus, demikian McKnigt, "sangat memadai."7 Oleh karena itu, adalah lebih baik untuk memahami kepenulisan 1 Petrus dalam pandangan yang tradisional.

1 Petrus adalah surat penggembalaan kepada beberapa komunitas Kristen yang tersebar (1:1). Mereka menghadapi banyak masalah dalam kehidupan mereka. Lingkungan mereka, menurut Robinson, "secara terus menerus melihat dan memperlakukan mereka sebagai 'pendatang dan orang asing' (paroikoi and parepidemoi dalam 1:1; 2:11)." $\mathrm{nal}$ ini mengimplikasikan bahwa "mereka rentan terhadap segala diskriminasi dan pembatasan politik, hukum, ekonomi dan sosial." ${ }^{\prime 9}$ Mereka juga menderita karena iman mereka (band. 3:14), serta berbagai pencobaan menguji iman mereka (1:6). Jadi, sang Rasul dan Penatua (band. 1:1; 5:1) "menulis kepada jemaat-jemaat yang baru tersebut untuk menuntun mereka

\footnotetext{
6Lihat Udo Schnelle, The History and Theology of the New Testament Writings(London: SCM Press, 1998), 400.

7Lihat Scot McKnight, The NIV Application Commentary: 1 Peter (Grand Rapids, MI: Zondervan, 1996), 28.

${ }^{8}$ Robinson, Some Missiological Perspectives from 1 Peter 2:4-10, 1. 9lbid., 1.
} 
kepada kedewasaan dan untuk menganggapi isu-isu yang berkaitan dengan interaksi mereka dengan dunia dimana mereka hidup yang cenderung memusuhi."10 Mereka dimotivasi untuk mempertahankan iman mereka sampai hari Yesus Kristus menyatakan diri (1:7).

\section{Identitas dan Misi}

Apakah hubungan antara identitas Kristen dan misi? Hal ini penting untuk didiskusikan karena jawabannya akan menunjukkan sejauh apa kaitan identitas dengan misi. Pemahaman yang benar akan identitas akan membawa orang Kristen kepada kesadaran akan tugas panggilannya. Steuernagel mengafirmasi hal ini dengan mengatakan bahwa "faktanya kedua hal tersebut sangat terkait erat karena tidak akan ada misi tanpa identitas."11 Dengan kata lain, identitas seseorang selalu menentukan misinya. Dan identitas yang khusus selalu diikuti dengan misi yang khusus pula. Dalam analogi yang sama, misi Kristen didasarkan pada identitas kristianinya. Tidak akan ada misi jika Gereja tidak mengetahui identitasnya. Dan saat orang percaya gagal untuk mengenal identitasnya sebagai gereja, biasanya, misi terabaikan. Oleh karena itu, mengenal identitas adalah sesuatu yang teramat penting. Semakin jelas identitas maka semakin jelas misi yang diemban.

\footnotetext{
${ }^{10}$ Mark Boyley, "1 Peter: A Mission Document?" dalamReformed Theological Review 63, no. 2 (2004): 74-75.

${ }^{11}$ Steuernagel, An Exiled Community as a Missionary Community, 15.
} 
Petrus secara jelas mengatakan di suratnya tentang identitas Kristen. Di dalam introduksi suratnya, ia menggunakan istilah khusus untuk menjelaskan siapa orang Kristen itu. Orang Kristen adalah "bangsa terpilih" (1:2; band. 2:9), yang ditranslasikan dari kata Yunani eklektos. Pemilihan memiliki banyak arti di dalam Alkitab. la berbicara tentang pemilihan individu-individu untuk suatu pekerjaan atau kehormatan dan hak istimewa; ada juga pemilihan terhadap bangsabangsa untuk hak-hak istimewa (UI. 7:6; Rm. 9:4); dan ada pula pemilihan individu-individu untuk hidup yang kekal (2 Tes. 2:13; Ef. 1:4; 1 Ptr. 1:2; Yoh. 13:18). ${ }^{12}$ Berdasarkan penjelasan ini, pemilihan orang percaya bersifat istimewa; orang percaya dipilih agar taat dan menerima percikan darah Yesus Kristus (1:2).

Dasar pemilihan ini adalah anugerah Allah yang besar (1:3, band. Ef. 1:5, 11). Dengan pemilihan ini, orang-orang menerima keselamatan. Mereka ditebus oleh darah Kristus (1:2); mereka datang kepada Yesus dan percaya kepada-Nya $(2: 4,7)$. Hal ini dijelaskan lebih jauh di dalam 1 Petrus 2:10, ketika Petrus berkata "kamu, yang dahulu bukan umat Allah, tetapi yang sekarang telah menjadi umatNya, yang dahulu tidak dikasihani tetapi yang sekarang telah beroleh belas kasihan." Keadaan ini, tentu saja, memberikan mereka identitas baru; mereka adalah orang-orang pilihan Allah. Tema pemilihan ini diulangi lagi di 1 Petrus 2:9. Dalam bagian ini, penjelasannya dilanjutkan. Petrus mengatakan, mereka adalah "bangsa yang

${ }^{12}$ Lihat Easton, "Election" dalam Easton Dictionary, Bible Work 7. 
terpilih, imamat yang rajani, bangsa yang kudus, umat kepunyaan Allah sendiri." Semua kriteria ini awalnya ditujukan kepada bangsa Israel (band. Kel. 19:5-6, Yes. 43:20, 61:6), namun kini menjadi identitas mereka.

Identitas ini, pada gilirannya, mengandung tugas yang harus dipenuhi yaitu "memberitakan perbuatan-perbuatan yang besar dari Dia." Blauw, sebagaimana dikutip oleh Robinson, membuat suatu analisa yang baik ketika ia berkata "pemahaman yang signifikan bahwa gereja sebagai umat Allah tidak eksis untuk dirinya sendiri, ditekankan secara khusus oleh posisi empatis dari hopos di ayat 9."13 Kata hopos ini digunakan sebagai kata sambung yang mengindikasikan tujuan, dll., yang memiliki arti dalam rangka." ${ }^{4}$ Itu berarti, berdasarkan ayat ini, Gereja adalah orang-orang yang dipilih "dalam rangka memberitakan perbuatan-perbuatan yang besar dari Dia yang telah memanggil engkau keluar dari kegelapan kepada terang-Nya yang ajaib." Identitas mereka, pada faktanya, membawa pada tugas khusus. Inilah natur orang Kristen. Orang Kristen dan misi tidak bisa dipisahkan karena misi tersebut melekat dalam identitas Kristen.

Tugas utama yang diungkapkan di ayat tersebut adalah bahwa Gereja dipanggil untuk 'memberitakan' perbuatan-perbuatan besar dari Dia. Istilah ini berasal dari kata Yunani exaggello, yang berarti

${ }^{13}$ Robinson, Some Missiological Perspectives from 1 Peter 2:4-10, 6. Untuk studi lebih lanjut, lihat J. Blauw, The Missionary Nature of the Church (London: Lutterworth, 1964), 128, 132.

${ }^{14}$ Lihat Gingrich, hopos dalam Greek NT Lexicon, Bible Work 7. 
REAL DIDACHE: JURNAL STT REAL BATAM Vol. 2 No. 1 (Maret 2017)

"menyampaikan, mendeklarasikan secara luas, atau memperkenalkan dengan pujian atau proklamasi, merayakan."15 Karena itu, dengan identitas mereka, Gereja akan "memberitakan, mendeklarasikan dan memproklamirkan" perbuatan-perbuatan Allah di dalam hidup mereka. Pemahaman ini tentunya mempengaruhi Gereja. Gereja eksis "dalam rangka” memproklamirkan perbuatanperbuatan Allah yang besar. Ini berarti, adalah bertentangan dengan ide Alkitab jika Gereja tidak hidup dalam misi. Robinson mengafirmasi hal ini dengan berkata, "sebuah jemaat yang tidak bersaksi adalah kontradiksi di dalam keberadaannya."16 Dan, "misi adalah sesuatu yang tidak terpisahkan dari eksistensi Gereja."17 Bahkan Barth, seperti dikutip oleh Robinson berkata, "Gereja eksis karena ia telah diutus dan sekarang ia aktif di dalamnya." 18 Petrus tentulah setuju dengan pemahaman ini. Tujuan eksistensi Gereja adalah untuk melaksanakan misi yang Allah telah tetapkan. Misi tersebut terkandung di dalam identitas Kristen seseorang.

\section{Penderitaan dan Misi}

Tidak dapat disangkal bahwa 1 Petrus mengandung tema tentang penderitaan di dalamnya. Orang percaya penerima surat

\footnotetext{
${ }^{15}$ Lihat Strong, exaggello dalam Bible Work 7.

${ }^{16}$ Robinson, Some Missiological Perspectives from 1 Peter 2:4-10, 7.

${ }^{17}$ Ibid., 6.

${ }^{18}$ lbid., 6.
} 
Petrus secara jelas digambarkan sebagai sedang mengalami beberapa bentuk penderitaan. "Berbagai-bagai pencobaan" menguji iman mereka (1:6). Mereka "difitnah" sebagai orang-orang durjana (2:12); mereka "menanggung penderitaan yang tidak harus mereka tanggung" (2:19). Meskipun demikian, mereka tidak boleh "membalas kejahatan dengan kejahatan, atau caci maki dengan caci maki, tetapi sebaliknya, hendaklah kamu memberkati..." (3:9), karena jika mereka menderita oleh karena kebenaran, mereka akan diberkati (3:14). Mereka tidak harus heran akan "nyala api siksaan" yang mereka sedang alami (4:12). Mereka "berbagi penderitaan Kristus" (4:13), "dinista karena nama Kristus" (4:14) dan "menderita sebagai orang Kristen" (4:16).

Berkaitan dengan penderitaan tersebut, beberapa sarjana mencoba menemukan apakah penderitaan itu diorganisasikan oleh negara atau tidak. Namun tampaknya sangat sulit untuk menyimpulkan demikian karena, sebagaimana Johnson berkata, "penganiayaan pertama yang demikian adalah bersifat lokal di Roma di bawah pemerintahan Nero, dan kita tidak mengetahui apapun tentang hal itu di Timur sampai masa Domitianus (93-96), dan karena tradisi menyatakan bahwa Petrus dibunuh di Roma pada masa Nero (64-68), jadi penderitaan ini bukanlah penganiayaan oleh negara."19 Jadi, dapat diasumsikan bahwa gambaran penderitaan orang percaya yang diungkapkan si Pengarang kitab mengacu pada sebuah konteks

\footnotetext{
19Luke Timothy Johnson, "1 Peter," dalam The Writings of the New Testament (Minneapolis: Fortress Press, 1999), 482-83.
} 
diskriminasi sosial..$^{20}$ Ini berarti mereka mengalamai penderitaan dari masyarakat sekitar mereka karena iman mereka. Namun ini sesungguhnya bukanlah situasi yang mengherankan karena itulah natur kekristenan dalam kaitannya dengan dunia (2:18-21band. Yoh. 16:2). Dalam perjumpaan antara perbuatan benar orang percaya dan kebiasaan orang tak percaya, demikian Brunk, "yang terakhir bereaksi secara negatif."21 Penderitaan yang sama juga dialami saudara-saudara mereka di seluruh dunia (5:9).

Apa kaitan antara misi dan penderitaan? Pada umumnya banyak yang akan berkata bahwa penderitaan akan membatasi misi. Bagaimanapun juga, penganiayaan dan penderitaan kelihatannya cenderung menghalangi misi. Namun Petrus tidak berpikir demikian. Meskipun mereka sedang dianiaya, dia mendorong mereka untuk tetap menjaga pengharapan mereka di dalam Kristus (1:13) karena Kristus juga telah menderita untuk mereka, menjadi teladan bagi mereka (2:21). Ini berarti, sekalipun mereka menderita, mereka perlu mempertahankan iman mereka, bahkan bersaksi melalui kehidupan mereka. Misi tidak dapat dibatasi oleh penderitaan karena bahkan dalam penderitaan, perbuatan baik orang-orang percaya akan bersinar kepada lingkungan mereka. Brunk mengafirmasi hal ini dengan berkata, "sikap kudus tak kenal kompromi mereka memiliki

\footnotetext{
20Johnson, 1 Peter, 483.

${ }^{21}$ George R. Brunk, "The Missionary Stance of the Church in 1 Peter,"Mission Focus 6, no. 5 (1978):70.
} 
dampak misionari bagi masyarakat."22 Oleh karena itu, penderitaan bisa menjadi keadaan yang signifikan untuk orang percaya melakukan misi. Bahkan, demikian Robinson, "tidaklah aneh jika kita memperhatikan bahwa martyreo, istilah untuk bersaksi di dalam Perjanjian Baru, bersamaan dengan berjalannya waktu telah mendapat arti yang mengaitkan kesaksian dan penderitaan."23 Penderitaan di dalam kekristenan tidak dapat membatasi misi sama sekali tapi justru sebaliknya.

Petrus menekankan fakta-fakta tersebut. Daripada mengeluh terhadap situasi yang dihadapi, dia meminta Gereja untuk berdiri teguh di dalam kasih karunia Allah (5:12). Bahkan dia mendesak para pembacanya agar memiliki cara hidup yang terpuji, karena hal itu memiliki dampak yang penting terhadap kesaksian mereka diantara bangsa-bangsa bukan Yahudi (2:12). Dalam ayat itu, Petrus menggunakan istilah Yunani doxasosin dengan modus subjunctive dan kala aorist untuk menggambarkan hasil dari cara hidup yang terpuji orang percaya. ${ }^{24}$ Itu berarti dalam pemahaman Petrus, adalah mungkin untuk membuat orang-orang non Yahudi itu menjadi percaya. Dan, karena ia menggunakan kala aorist untuk menggambarkan kemungkinan ini, dapat dipastikan bahwa ketika orang percaya hidup dengan cara yang terpuji, hasilnya sedang terjadi. Hal ini sama dengan analisa Brunk ketika dia berkata, "hasil

\footnotetext{
22Brunk, The Missionary Stance of the Church in 1 Peter, 73.

${ }^{23}$ Robinson, Some Missiological Perspectives from 1 Peter 2:4-10, 2.

${ }^{24}$ Lihat doxasosin dalam Bible Work 7.
} 
penginjilan, bagaimanapun juga, adalah bergantung pada konsistensi dan ketekunan Gereja dalam cara hidup yang berbeda." ${ }^{25}$ Oleh karena itu, dapat disimpulkan bahwa penderitaan merupakan salah satu cara yang bisa dipakai untuk memproklamirkan iman Kristen kepada orang yang tidak percaya, secara khusus ketika Gereja menghadapinya dengan cara hidup yang terpuji.

\section{Cara-cara Misi}

Telah jelas terlihat bahwa 1 Petrus adalah sebuah surat misi. Sejauh ini, telah diuraikan juga bahwa surat ini memiliki hubungan yang sangat penting dengan misi secara umum. Selanjutnya, akan diuraikan cara-cara misi menurut 1 Petrus. Pertanyaan yang perlu dijawab adalah "Apakah cara-cara misi yang Petrus sarankan?" Jawabannya akan menolong untuk menggenapi misi orang percaya sebagai gereja.

\section{Misi melalui Pelayanan}

Petrus berkata bahwa sebagaimana mereka datang kepada Kristus, orang percaya juga adalah batu hidup karena mereka terikat kepada Yesus, sang Batu Hidup. Berdasarkan identitas ini Petrus juga mengatakan bahwa Gereja dibangun menjadi suatu rumah rohani, bagi suatu imamat kudus, untuk mempersembahkan 
persembahan rohani kepada Allah (2:5). Tentu saja, Bait Suci historis di Yerusalem merupakan akar dari identitas ini, dan kini Petrus mengaplikasikan symbol ini kepada komunitas Kristen (band. Ef. 2:20-22; 1 Kor. 3:16-17; 2 Kor. 6:16; 1 Tit. 3:15; Ibr. 3:6). Itu berarti, dalam pandangan Petrus, tidak ada lagi bangunan atau institusi, demikian Senior, "tetapi suatu komunitas yang hidup atau 'rumah tangga' karena itulah satu dari konotasi alternatif dari istilah Yunani oikos."26 Gereja adalah suatu komunitas, suatu komunitas kudus yang hidup.

Identitas ini memiliki arti yang penting bagi mereka. Sebagai batu yang hidup dan imamat yang kudus, mereka diminta untuk membangun suatu rumah rohani dan mempersembahkan persembahan yang rohani. Apakah tujuan dari frasa-frasa tersebut? Kelihatannya Petrus ingin para pembacanya mengetahui bahwa dalam komunitas Kristiani, setiap orang percaya adalah imam. Sebagaiman Minear berkata, "Surat ini telah diklaim, mungkin secara tepat, mendukung doktrin keimaman semua orang percaya."27 Paulus berbicara hal yang serupa tentang "membangun" Gereja dalam 1 Korintus 14:12. Efesus 4:11-12 juga mencatat berbagai bentuk pelayanan di dalam komunitas dan berkata bahwa tujuan dari semua 'karunia' tersebut adalah "untuk memperlengkapi orang kudus... bagi pembangunan tubuh Kristus." Nasihat-nasihat ini tentunya berbagi

${ }^{26}$ Donald P. Senior, 1 Peter, 59.

${ }^{27}$ Paul S. Minear, "The House of Living Stones I Peter 2:4-12,"Ecumenical Review 34, no. 3 (1982): 245. 
perspektif yang sama. Semuanya menekankan keimamam semua orang percaya. Dan tidak ada seorangpun yang bisa menyangkali kebenaran ini.

Jadi, bagaimana caranya orang percaya menjadi pelayan? Tentu saja jawabannya adalah dengan melaksanakan misi. Setiap orang Kristen memiliki panggilan dan tanggung jawab yang sama karena, demikian Grimes, "semua orang yang menerima panggilan dicangkokkan kepada organisme hidup dan mereka menjadi cabangcabang yang daripadanya akan keluar buah."28 Atau dalam bahasa Petrus, semua orang Kristen dipanggil untuk membangun komunitas rumah spiritual. Dengan kata lain tanggung jawab ini, demikian Boyley, "sangat baik dijelaskan sebagai suatu statemen umum yang mengacu kepada aktivitas khusus yang diacu pada ayat-ayat berikut: proklamasi perbuatan-perbuatan Allah yang besar (2:9)."29 Dalam pikiran Petrus, misi dapat dilakukan dengan melayani: dengan membangun sebuah komunitas Kristen. Hal ini, tentu saja, berbicara tentang misi yang dilakukan orang percaya baik ke dalam maupun ke luar komunitas Kristen.

Misi melalui Perbuatan 1958), 39.

${ }^{28}$ Howard Grimes, The Church Redemptive (Nashville: Abingdon Press,

${ }^{29}$ Boyley, 1 Peter: A Mission Document, 79. 
Petrus menasihati para pembacanya untuk memiliki sikap yang terpuji dalam hidup mereka $(2: 12,15 ; 3: 1)$. Dia mengimplikasikan bahwa perbuatan-perbuatan ini, pada gilirannya akan menyebabkan orang-orang di sekitar mereka menjadi percaya. Oleh sebab itu, berdasarkan statemen ini dapat disimpulkan bahwa misi dapat dilakukan melalui perbuatan.

Sikap hidup orang percaya memiliki peran penting dalam misi. Dan Petrus benar-benar mempertimbangkan hal tersebut. Sebagaimana Boyley berkata, "keyakinan utama dalam nasihat Petrus berkaitan dengan interaksi terhadap orang-orang yang tidak percaya adalah berdasarkan gaya hidup." 30 Surat itu secara konsisten memanggil kepada kesaksian yang indah melalui "cara hidup yang baik" $(2: 12,15$, dan 20). Inilah cara warga negara Kristen (2:13-17) atau budak-budak Kristen (2:18-25) pertama kali memberitakan Injil. Nasihat yang sama diberikan kepada para istri yang suaminya "'tidak taat kepada firman" (3:1).

Contoh yang sangat menarik muncul di dalam 1 Petrus 3:1. Ketika Petrus menggambarkan ketundukan istri Kristen, dia menyatakan bahwa dengan sikap mereka, para istri bisa memenangkan suami mereka bahkan tanpa kata-kata. Ini berarti orang Kristen dapat memenangkan orang yang tidak percaya tanpa kata-kata. Tentu saja hal ini bukan merupakan syarat mutlak di dalam memenangkan orang, tapi signifikansinya masih tetap bisa

30Boyley, 1 Peter: A Mission Document, 79. 
dipertimbangkan. Perbuatan seseorang seringkali menjadi bahan pertimbangan untuk melihat apakah orang tersebut dapat dipercaya atau tidak. Brunk sangat menarik dalam menggambarkan proses ini. Dia berkata, "pengaruh evangelistik dari 'perbuatan baik' dimulai dengan tindakan mengamati perbuatan baik. Pengamatan memimpin kepada pemahaman. Hasil akhirnya adalah antara dimenangkan kepada iman Kristen (3:1) atau menjadi diam atau merasa malu (2:15; 3:16)."31 Oleh karena itu, orang Kristen diminta untuk memiliki "cara hidup yang baik" diantara masyarakat sekitar mereka karena itu merupakan kehendak Allah (2:15). Hal ini sangatlah penting dalam kehidupan orang percaya karena, sebagaimana Johnson berkata, "adalah jelas bahwa sikap panjang sabar, tunduk dan setia yang terdapat dalam image orang Kristen ditujukan untuk menjadi contoh bagi seluruh masyarakat"32 Dan hal demikian adalah benar. Kadangkala perbuatan jauh lebih ampuh berbicara dari pada katakata dalam memenangkan orang bagi Kristus.

\section{Misi melalui Perkataan}

Yang terakhir, cara melaksanakan misi yang muncul di dalam 1 Petrus adalah bahwa misi dapat dilaksanakan melalui perkataan. Tidak ada keraguan tentang hal ini. Yesus, sebelum kenaikan-Nya ke

${ }^{31}$ Brunk, The Missionary Stance of the Church in 1 Peter, 75.

32Johnson, The Writings of the New Testament, 488. 
surga berkata kepada para murid-Nya bahwa mereka "akan menjadi saksi-saksi-Nya" (Kis. 1:8). Petrus, mengulangi perintah gurunya, menyatakan kepada para pembacanya bahwa mereka harus "memberitakan perbuatan-perbuatan yang besar dari Dia" (2:9). Lebih lagi, dia menambahkan bahwa mereka harus "siap sedia pada segala waktu untuk memberi pertanggungan jawab kepada tiap-tiap orang yang meminta pertanggungan jawab dari kamu tentang pengharapan yang ada padamu" (3:15). Dalam ayat tersebut, Petrus menggunakan istilah Yunani apologia untuk menggambarkan pentingnya hal tersebut. Menurut Verbrugge, "kata ini terutama digunakan dalam setting pengadilan pada masa Yunani klasik, disaat seseorang membela dirinya dari suatu tuntutan tertentu."33 Tentu saja, Petrus serius saat ia menggunakan kata tersebut kepada para pembacanya. Keseriusan tersebut sebanding dengan pentingnya membagi iman kepada orang lain. Dan adalah penting bagi Gereja untuk mempersiapkan diri untuk melakukannya.

Kata-kata sangat diperlukan dalam melaksanakan misi agar apa yang ingin diungkapkan dapat terkomunikasikan dengan lebih efektif. Brunk mengafirmasi hal ini dengan berkata, "Pemaparan mengisyaratkan sesuatu telah hadir dan diketahui namun belum dipahami". ${ }^{34}$ Orang-orang memerlukan kata-kata untuk berkomunikasi. Dan orang Kristen harus menggunakan cara yang

\footnotetext{
${ }^{33}$ Verlyn D. Verbrugge, "apologia"New International Dictionary of New Testament Theology (Grand Rapids, MI: Zondervan, 2000), 63.

${ }^{34}$ Brunk, The Missionary Stance of the Church in 1 Peter, 76.
} 
sama dalam melakukan misi, memperkatakan pengharapan mereka di dalam Kristus dalam rangka memproklamirkan Injil kepada masyarakat di sekitar mereka.

\section{Redefinisi Misi}

Kita telah melihat bahwa Surat 1 Petrus adalah sebuah dokumen misi. Surat ini memberitahu identitas kita dan signifikansi hal tersebut terhadap misi kita sebagai orang percaya. Melalui surat ini kita juga bisa melihat bahwa misi dapat saja dilakukan, bahkan dalam situasi penderitaan yang dalam sekalipun. Oleh karena itu, kita harus memikirkan ulang konsep kita tentang misi. Melalui surat ini kita melihat beberapa konsep yang bisa membantu kita mendefinisikan misi.

Pertama, misi sangat berkaitan dengan identitas orang percaya. Identitas yang kita terima setelah kita percaya kepada Kristus selalu terkait dengan misi. Bahkan di dalam identitas itu terkandung misi yang kita harus jalani. Semua status dan berkat yang kita terima terikat erat dengan tugas dan panggilan kita sebagai Gereja. Karena itu, orang Kristen yang tidak melakukan misi dalam hidupnya adalah kontradiksi dalam naturnya karena menjadi seorang Kristen berarti memanggul misi di pundaknya.

Kedua, misi dapat dilaksanakan dalam segala situasi. Surat 1 Petrus adalah sebuah contoh betapa misi tidak tergantung kepada 
REAL DIDACHE: JURNAL STT REAL BATAM Vol. 2 No. 1 (Maret 2017)

apapun selain kemauan untuk tunduk pada firman Tuhan. 1 Petrus membuktikan bahwa penderitaan sekalipun tidak bisa menjadi alasan bagi Gereja untuk tidak melakukan misi. Yesus telah memberikan teladan misi melalui penderitaan (3:18), dan Gereja-Nya wajib mengikuti-Nya. Orang Kristen harus melaksanakan misi apapun situasinya.

Ketiga, misi adalah kehidupan seluruh jemaat. Melalui surat 1 Petrus kita dapat melihat bahwa sebagai batu-batu hidup, kita harus datang kepada Yesus, sang Batu Hidup dan membangun suatu rumah rohani. Itu berarti kehidupan kita sebagai Gereja tidak dapat dipisahkan dari Kristus-sumber kehidupan kita, dan dari sesama. Membangun suatu rumah rohani adalah tujuan hidup kita dan itu hanya dapat dilakukan ketika semua orang terlibat melaksanakan bagiannya. Melalui kesatuan kita dengan Kristus dan kehidupan jemaat Kristen, iman kita akan bersinar kepada dunia.

\section{KESIMPULAN}

Telah dikatakan bahwa 1 Petrus adalah surat misi. Observasi menyeluruh terhadap kitab ini memberi bukti bahwa kitab ini mengandung perspektif misi. Boyley mengatakan, "kitab ini adalah 
sebuah dokumen misi." ${ }^{35}$ Dari 1 Petrus kita mengetahui natur Gereja. la menunjukkan kepada kita bahwa identitas kita mengandung misi.

Dengan demikian, hal penting yang perlu kita renungkan setelah membaca surat ini adalah seberapa besar passion kita akan misi? 1 Petrus memberikan gambaran yang hidup dari Gereja purba. Mereka menderita karena iman mereka. Meskipun demikian mereka tidak mengeluh melainkan tetap bertahan dalam iman sambil melakukan hal-hal terpuji. Lebih lagi, mereka diminta untuk memproklamirkan iman mereka terhadap masyarakat di sekitar mereka. Dan tampaknya tidak ada keraguan bahwa mereka tidak melakukannya.

Kini kita hidup di era kebebasan. Meskipun harus diakui bahwa di tempat tertentu kebebasan tersebut tidak diterapkan, namun, ada banyak tempat di dunia dimana Injil dapat diberitakan. Masihkah kita memiliki semangat misi? Apakah kita masih tergerak ketika mendengar ungkapan: "wining the lost at any cost"? Apakah kita sebagai Gereja masih menyadari bahwa sikap dan perbuatan kita adalah penting dalam memenangkan jiwa? Akankah kita membuka mulut dan menyampaikan Injil kepada sesama kita? Pertanyaanpertanyaan ini perlu mendapat tanggapan segera jika kita ingin melihat Injil tersebar sampai ke ujung bumi. Namun apapun jawabannya, Surat 1 Petrus telah memberi kita pola tentang bagaimana kita dapat melakukan misi. Hal ini setidaknya memberi 
REAL DIDACHE: JURNAL STT REAL BATAM Vol. 2 No. 1 (Maret 2017)

kita nasihat bahwa-seperti para pembaca awal surat ini, kita harus bertahan dalam iman apapun situasinya, sambil memberitakan perbuatan-perbuatan besar dari Allah yang telah memanggil kita dari kegelapan kepada terang-Nya yang ajaib. 


\section{KEPUSTAKAAN}

Bosch, D. J. Transforming Mission: Paradigm Shifts in Theology of Mission. New York: Orbis Books, 1991.

Boyley, Mark. "1 Peter: A Mission Document?" Dalam Reformed Theological Review 63, no. 2 (2004).

Brunk,George R. "The Missionary Stance of the Church in 1 Peter." Dalam Mission Focus 6, no. 5 (1978).

Glasser, Arthur F., and Donald A. McGavran. Contemporary Theologies of Mission. Grand Rapids, Ml.: Baker Book House, 1983.

Grimes, Howard. The Church Redemptive. Nashville: Abingdon Press, 1958.

Johnson,Luke Timothy. "1 Peter." Dalam The Writings of the New Testament. Minneapolis: Fortress Press, 1999.

McKnight, Scot. The NIV Application Commentary: 1 Peter. Grand Rapids, MI: Zondervan, 1996.

Minear, Paul S. "The House of Living Stones I Peter 2:4-12." Dalam Ecumenical Review 34, no. 3 (1982).

Robinson, P.J. "Some Missiological Perspectives from 1 Peter 2:410." Dalam Missionalia 17 (1989).

Schnelle,Udo. The History and Theology of the New Testament Writings. London: SCM Press, 1998.

Senior, Donald P. Sacra Pagina: 1 Peter. Editor Daniel J. Harrington. Collegeville, Minnesota: The Liturgical Press, 2003. 
REAL DIDACHE: JURNAL STT REAL BATAM Vol. 2 No. 1 (Maret 2017)

Steuernagel, Valdir R. "An Exiled Community as a Missionary Community. A Study based on 1 Peter 2:9, 10." Dalam Evangelical Review of Theology 10 (1986).

Verbrugge,Verlyn D. "Apologia" New International Dictionary of New Testament Theology. Grand Rapids, MI: Zondervan, 2000. 